\title{
The Effect of Job Stress and Job Satisfaction on Employee Performance PT Famed Calibration
}

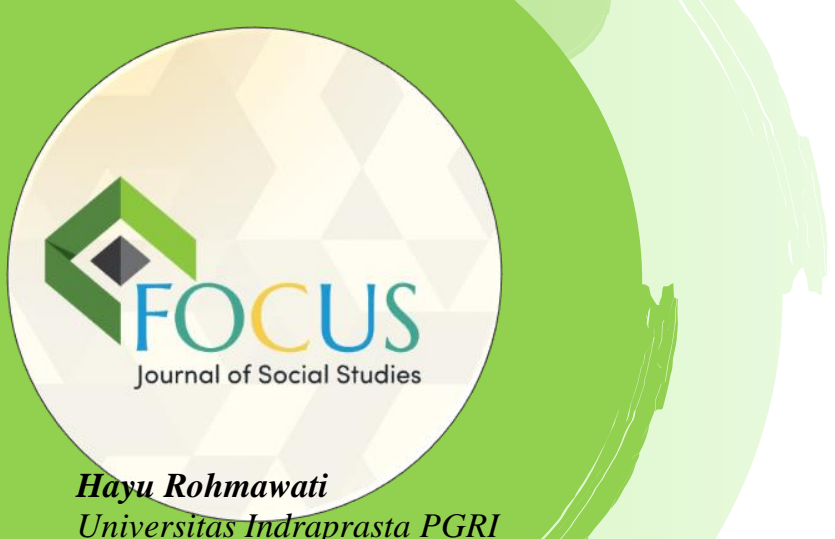

\author{
Pengaruh Stres Kerja dan Kepuasan Kerja terhadap Kinerja \\ Karyawan PT Famed Calibration
}

Universitas Indraprasta PGRI

Jl. Raya Tengah No.80, RT.6/RW.1,

Gedong, Ps. Rebo, Kota Jakarta Timur,

DKI Jakarta 13760.

hayurhmawati96@gmail.com

+62 856-9702-7740

\section{Siska Maya}

Universitas Indraprasta PGRI

Jl. Raya Tengah No.80, RT.6/RW.1,

Gedong, Ps. Rebo, Kota Jakarta Timur,

DKI Jakarta 13760.

\section{Hamzah Robbani}

Universitas Indraprasta PGRI

Jl. Raya Tengah No.80, RT.6/RW.1,

Gedong, Ps. Rebo, Kota Jakarta Timur,

DKI Jakarta 13760.

21pb01004@student.kuis.edu.my

\section{DOI}

https://doi.org/10.37010/fcs.v1i2.354

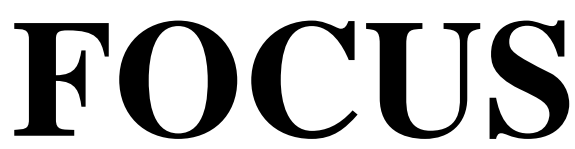

\section{Journal of Social Studies}

\section{Vol. 1 No. 2 AGUSTUS}
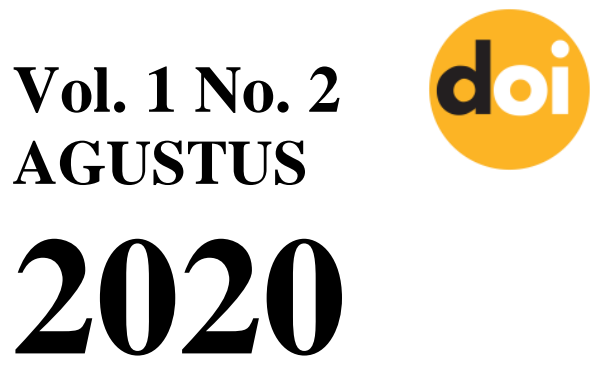


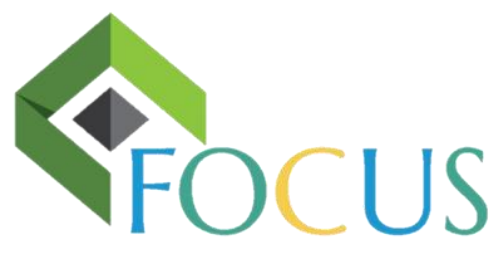

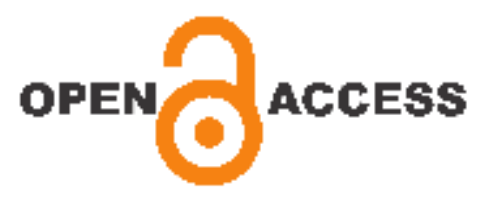

PENDAHULUAN

PT Famed Calibration adalah perusahaan yang bergerak di bidang penjualan, jasa kalibrasi, jasa uji kesesuaian X-Ray dan jasa service peralatan kesehatan. PT Famed Calibration memiliki visi misi ingin lebih meningkatkan kemampuan dan profesionalisme dalam pemenuhan sasaran mutu dengan mengikuti perkembangan teknologi yang mutakhir serta mempertahankan komitmen terhadap jaminan mutu. Servis dan produk terbaik, dengan orientasi kepuasan pelanggan, dan beroperasi dengan efisiensi yang inovasi, teknologi yang mendukung, fasilitas, dan karyawan yang kompeten dan berkembang. Kantor pusat perusahaan ini terletak di Jl. Pondok Cibubur No. 11 Blok. E, Depok.

Hasil pengamatan peneliti mendapatkan beberapa informasi mengenai kepuasan kerja yaitu mengenai pekerjaan yang kurang menantang secara mental, adalah tidak terdapat variasi pekerjaan yang menuntut munculnya kreativitas, contohnya yaitu pekerjaan yang dilakukan hanya berhadapan dengan komputer disetiap harinya yang tentunya dalam konteks ini yaitu karyawan yang bekerja di kantor. Selanjutnya reward yang diberikan sudah sesuai, tetapi untuk waktu tertentu seperti saat permintaan sertifikat dan jasa kalibrasi pada akhir tahun hingga awal tahun (Oktober-Maret) yang selalu berjumlah lebih banyak dibandingkan dengan bulan-bulan lainnya dilihat dari waktu dan tenaga yang diberikan oleh karyawan di kantor maupun di lapangan, dirasakan reward yang diberikan tidak sesuai. Kondisi kerja yang kurang mendukung, yaitu kurangnya alat pendingin ruangan, selain berguna untuk kenyamanan karyawan, juga dapat menjaga alat kalibrator di Lab. Kalibrasi pun dapat terjaga kualitasnya, namun untuk kondisi kerja pada kantor PT Famed Calibration sudah sangat baik mengenai fasilitas yang ada, perlengkapan kerja dan suasana kerja pun dirasa sangat nyaman, untuk kolega yaitu masih sering kali tidak dapat bekerja sama dengan baik, yaitu pada kolega eksternal.

Berdasarkan latar belakang tersebut maka akan diteliti terkait adakah pengaruh yang signifikan antara Pengaruh Stres Kerja dan Kepuasan Kerja terhadap Kinerja Karyawan PT Famed Calibration. Penelitian ini bertujuan untuk mengetahui pengaruh stress kerja terhadap kinerja karyawan pada PT Famed Calibration, untuk mengetahui pengaruh kepuasan kerja terhadap kinerja karyawan pada PT Famed Calibration, dan untuk mengetahui pengaruh stress kerja dan konflik kerja terhadap kinerja karyawan pada PT Famed Calibration.

\section{METODE PENELITIAN}

Penelitian ini dilaksanakan pada seluruh karyawan di PT. Famed Calibration yang beralamat di Jl. Pondok Cibubur Blok. E. No. 11, Depok. Dalam penelitian ini, peneliti menggunakan metode kuantitatif. Penelitian yang dilakukan pada populasi (tanpa diambil sampel) jelas akan menggunakan statistik deskriptif dalam analisanya. Statistik deskriptif digunakan bila peneliti hanya ingin mendeskripsikan data sampel, dan tidak ingin membuat kesimpulan yang berlaku untuk populasi dimana sampel diambil.

Berdasarkan pada tempat penelitian yang telah ditetapkan, maka populasi yang dijadikan objek dalam penelitian ini adalah karyawan yang ditempatkan di PT Famed Calibration sebanyak 70 orang ( Dokumen Kantor PT Famed Calibration ). Sampel dalam penelitian ini adalah berjumlah 70 orang karyawan di PT Famed Calibration. Dengan demikian teknik pengambilan sampel yang digunakan dalam penelitian ini adalah teknik sampling jenuh. Adapun teknik pengambilan data yang peneliti gunakan adalah data sekunder yaitu data internal dan data eksternal, observasi dan kuesioner. Untuk mendapatkan kualitas data, peneliti melakukan validitas data dengan melakukan analisis pada faktor keabsahan data (validitas data). 


\section{HASIL DAN PEMBAHASAN}

\section{Hasil}

Berdasarkan hasil olah data yang dilakukan, didapatkan nilai ttabel sebesar $=1,668$ dan thitung sebesar $=$ 1,718. Adapun nilai regresinya adalah $\hat{Y}=15,202+0,199 X 1+0,239 X 2$. Dari uji ANOVA atau Uji F didapat nilai F hitung sebesar 10,660 nilai ini lebih besar dari $F$ tabel yaitu 3,12 atau Fhitung 10,660 > F tabel 3,12 dengan probabilitas 0.000 . Karena nilai probabilitas jauh lebih kecil dari 0,05 maka model regresi dapat digunakan untuk memprediksi kinerja karyawan atau dapat dikatakan bahwa kedua variabel bebas stress kerja dan kepuasan kerja berpengaruh terhadap kinerja karyawan.

Dari hasil output SPSS dapat disimpulkan bahwa nilai t hitung variabel X1 lebih besar dari pada nilai $t$ table $(1,718>1,668)$ dengan tingkat signifikan di atas 0,05 yaitu 0,90 , dan $t$ hitung variabel X2 lebih besar dari pada nilai $\mathrm{t}$ tabel $(3,332>1,668)$ tingkat signifikan dibawah 0,05 yaitu 0,001 . Bedasarkan cara pengambilan keputusan pengujian parsial dalam analisis regresi dapat diimpulakan sebagai berikut :

1. Variabel stres kerja secara parsial berpengaruh tidak signifikan terhadap kinerja karyawan.

2. Variabel kepuasan kerja secara parsial berpengaruh signifikan kinerja karyawan.

\section{Pembahasan}

Berdasarkan hasil analisis $\mathrm{F}$ hitung $>\mathrm{F}$ tabel 10,660 > 3,12 dengan tingkat signifikan dibawah 0,05 yaitu 0,000. Secara analisis stres kerja dan kepuasan kerja secara simultan berpengaruh terhadap kinerja karyawan.. Variabel stres kerja yang terdiri dari beberapa indikator yaitu: untuk tuntutan tugas, tuntutan peran, tuntutan antarpribadi, struktur organisasi dan kepemimpinan organisasi. Kepuasan kerja yang terdiri dari beberapa indikator yaitu: pekerjaan, gaji, rekan kerja, atasan dan promosi. Dan kinerja karyawan yang terdiri dari beberapa indikator yaitu: kualitas, kuantitas, ketepatan waktu dan kerja sama.

Berdasarkan uji t bahwa nilai stres kerja t hitung 1,718 > 1,668 t tabel dan nilai signifikan lebih besar 0,05 yaitu 0,090 yang artinya bahwa stres berpengaruh negatif dan tidak signifikan terhadap Kinerja Karyawan. Hasil ini menunjukkan bahwa $\mathrm{H} 3$ ditolak.Jika semakin tinggi tingkat stres kerja karyawan maka akan meningkatkan perspektif serta ancaman yang dapat menimbulkan hasil negatif yang nantinya akan mempengaruhi kinerja karyawan seperti: kemampuan, motivasi, lingkungan kerja serta kepemimpinan. Karyawan yang sering mengalami stres kerja tidak dapat mengatur waktu serta adanya desakan waktu, tekanan dan adanya yang berlebihan seperti tumpukan pekerjaan sehingga dapat menurunkan tingkat kinerja karyawan.

Berdasarkan uji t bahwa kepuasan kerja t hitunglebih besar dari nilai $\neg(3,382>1,668)$ tingkat signifikan dibawah 0,05 yaitu 0,001 yang artinya bahwa kepuasan kerja berpengaruh Positif dan signifikan terhadap kinerja karyawan. Hasil ini menunjukkan bahwa $\mathrm{H} 2$ diterima. Apabila kepuasan kerja dilakukan dengan lebih atau sangat tepat maka akan mempengaruhi kinerja ke arah positif.

\section{PENUTUP}

Berdasarkan hasil penelitian dan pembahasan Pengaruh Stres Kerja dan Kepuasan Kerja Terhadap Kinerja Karyawan pada PT. Famed Calibration. Hal ini dibuktikan dengan nilai koefisien korelasi sebesar 0,491 sehingga hubungan antara stres kerja dan kepuasan kerja terhadap kinerja karyawan pada PT Famed Calibration. adalah berpengaruh sedang

Dari hasil uji simultan yang telah dilakukan pada hipotsis pertama dapat disimpulkan bahwa stres kerja dan kepuasan kerja secara bersama-sama berpengaruh negative dan signifikan terhadap terhadap Kinerja Karyawan pada PT Famed Calibration. Hal ini berarti karyawan memiliki stres kerja yang baik dan didukung, 


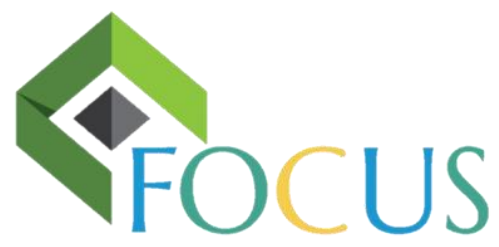

orewOAacesss

memiliki kepuasan kerja yang tinggi terhadap organisasi sehingga mampu untuk berprestasi dan kinerja yang mampu mengoptimalkan. Begitu juga sebaliknya.

Berdasarkan kesimpulan yang telah dikemukakan di atas, maka peneliti menyarankan bagi perusahaan untuk dapat mengurangi stress kerja karywan pada PT Famed Calibration, sebaiknya perusahaan lebih memperhatikan lagi kondisi-di sekitar tempat kayawan bekerja dan gejala-gejala stress yang sedang dihadapi oleh karyawan perusahan, kemudian dapat memberikan solusi seperti mengadakan refreshing, konseling, evalusi kerja karyawan dan lain sebaginya. Yang mampu mengurangi stress kerja.

Agar kepuasan kerja dan kinerja karyawan perusahaan meningkat, maka perusahaan dapat lebih memperhatikan reward, insentif dan sistem penggajian yang lebih baik. Sehingga kinerja karyawan menjadi lebih baik karena kepuasan kerja yang mereka dapatkan. Hasil penelitian terhadap faktor-faktor yang mempengaruhi stress kerja karyawan PT Famed Calibration ini masih perlu disempurnakan oleh penelitian serupa dengan sejumlah perusahan-perusahaan lainnya, sehingga dapat mewakili keterpaduan fakto-faktor yang mempengaruhi stress kerja dan kepuasan kerja karyawan.

\section{DAFTAR PUSTAKA}

AA. Anwar Prabu Mangkunegara. (2014). Manajemen Sumber Daya Manusia Perusahaan, Bandung: PT. Remaja Rosdakarya.

Gibson, James L., Donnelly Jr, James H., Ivancevich, John M., Konopaske, Robert (2012). Organizationa Behavior, Structure, Processes, Fourteenth Edition (International Edition).1221 Avenue of The Americas, New York, NY 10020: McGraw-Hill.

Kopmans, L; Bernaard, C.M; Hildebrandt, Vincent.H; Vet, H.C.W; De, Beek, A.J. Construct Validity of the Individual Work Performance Questionnaire. Journal of Occupational and Environmental Medicine: 2014, 56(3), 331- 337.

Nasrudin, Endin. (2010). Psikologi Manajemen. Bandung: CV. Pustaka Setia (Anggota IKAPI Jabar).

Robbins, S.P., dan Timothy A Judge. (2014). Perilaku Organisasi. Salemba Empat: Jakarta.

Siregar. Syofian. (2014). Metode penelitian kuantitatif dilengkapi dengan perbandingan perhitungan manual dan SPSS. Jakarta: Kencana.

Sugiyono. (2010.) Metode Penelitian Pendidikan Pendekatan Kuantitatif, Kualitatif, dan R\&D. Bandung: Alfabeta.

Nasyadizi N.N. Kusdi Rahardjo dan Ika Ruhana (2016). Pengaruh Stres Kerja dan Kepuasan Kerja terhadap Kinerja Karyawan (Studi Pada Karyawan PT Jasa Raharja (Persero) Cabang Jawa Timur di Surabaya). Jurnal Administrasi Bisnis (JAB), Vol. 31 No. 1 Februari 2016. Diakses pada 24 Desember dari http://administrasibisnis.studentjournal.ub.ac.id/index. php/jab/article/view /1206/1388 